This work was supported in part by Cardiology Research Foundation, Washington, DC, USA.

1 Nishimura RA, Edwards WD, Warnes CA, Reeder GS Holmes DR, Tajik AJ, et al. Intravascular ultrasound Am Coll Cardiol 1990;16:145-54.

2 Mintz GS, Popma JJ, Pichard AD, Kent KM, Satler LF, Chuang YC, et al. Patterns of calcification in coronary artery disease: a statistical analysis of intravascular ultrasound and coronary angiography in 1155 lesions. Circulation 1995;91:1959-65.

3 Fitzgerald P, Ports T, Yock P. Contribution of localized calcium deposits to dissection after angioplasty. An observational study using intravascular ultrasound. Circulation 1992;86:64-70.

4 Matar FA, Mintz GS, Pinnow E, Javier SP, Popma JJ, Kent $\mathrm{KM}$, et al. Multivariate predictors of intravascular ultrasound endpoints after directional coronary atherectomy. 7 Am Coll Cardiol 1995;25:318-24.

5 Mintz GS, Popma JJ, Pichard AD, Kent KM, Satler LF, Chuang YC, et al. Limitations of angiography in the assessment of plaque distribution in coronary artery disease: a systematic study of target lesion eccentricity in ease: a systematic study of target lesion

6 Duissaillant GD, Mintz GS, Pichard AD, Kent KM, Satler LF, Popma J, et al. Intravascular ultrasound identification of calcified intraluminal lesions misdiagnosed as tion of calcified intraluminal lesions misdiagnosed as thrombi by coronary angiography. Am Heart f. [In press.]
7 Mintz GS, Painter JA, Pichard AD, Kent KM, Satler LF, Popma JJ, et al. Atherosclerosis in angiographically normal coronary artery reference segments: an untravascular ultrasound study with clinical correlations. $¥ \mathrm{Am} \mathrm{Coll}$ Cardiol 1995;25:1479-85.
8 Stone GW, Linnemeier T, St Goar FG, et al. Improved outcome of balloon angioplasty with intracoronary ultrasound guidance-core lab angiographic and ultrasound results from the CLOUT study [abstract]. $\mathcal{F} \mathrm{Am}$ Coll results from the Cliol 1996;27:155A
Cardi

9 Fuessl RT, Mintz GS, Pichard AD, Kent KM, Satler LF, Popma JJ, et al. In vivo validation of intravascular ultrasound length measurements using a motorized transducer pullback device. Am f Cardiol 1996;77:1115-18.

10 Hoffmann R, Mintz GS, Dussaillant GR, Popma JJ Pichard AD, Satler LF, et al. Patterns and mechanisms of instent restenosis: a serial intravascular ultrasound study. Circulation 1996;94:1247-54.

11 Mintz GS, Popma J, Pichard AD, Kent KM, Satler LF Chuang YC, et al. Intravascular ultrasound predictors of restenosis following percutaneous transcatheter coronary revascularization. $\mathcal{f} \mathrm{Am}$ Coll Cardiol 1996;27:1678-87.

12 Mintz GS, Popma JJ, Pichard AD, Kent KM, Satler LF, Wong SC, et al. Arterial remodeling after coronary angioplasty: a serial intrascular ultrasound study. Circulation 1996;94:35-43.

13 The Guide Trial Investigators. IVUS-determined predictors of restenosis in PTCA and DCA: an interim report from the GUIDE trial, phase II [abstract]. Circulation 1994;90:123.

14 Mintz GS, Fitzgerald PF, Kuntz RE, et al. Lesion site and reference segment remodeling after directional coronary atherectomy: an analysis from the optimal atherectomy restenosis study [abstract]. Circulation 1995;92:193.

15 Hong MK, Wong SC, Pichard AD, Satler LF, Bucher T, Morgan C, et al. Long-term results of patients enrolled in the Anti-PLatelet treatment After intravascular Ultrasound guided optimal Stent Expansion (APLAUSE) tria [abstract]. Circulation 1996;94:I686.

\title{
Do we have enough evidence to insist we have IVUS?
}

\author{
Ian R Starkey
}

The use of intravascular ultrasound (IVUS), a method of imaging the wall of the coronary artery, complements the information obtained by coronary angiography, which defines the contour of the vessel lumen. IVUS demonstrates that significant mural disease is almost invariably present in angiographically normal segments of "focally" diseased coronary arteries, ${ }^{1}$ and has shown obstructive disease in patients with coronary arteries judged angiographically to be normal or near normal, ${ }^{2}$ which might justify its availability, at least as a supraregional service.

IVUS has been used to guide selection of the device used for percutaneous interventional treatment of coronary lesions but it has yet to be shown that this approach influences clinical outcome, and few interventional centres offer routine pre-interventional IVUS imaging and a choice of interventional devices that includes three different atherectomy catheters and an excimer laser! ${ }^{3}$

The demonstration by IVUS that coronary stents deployed at nominal balloon pressure are usually under expanded was an invaluable contribution. ${ }^{4}$ We now appreciate the need for optimal stent deployment, but it is unclear whether the routine use of IVUS guidance is actually essential for optimal stenting. The remarkable results obtained in the Benestent II pilot study, for example, were obtained without the routine use of this technique. ${ }^{5}$

The use of IVUS will continue to help our understanding of coronary artery disease. As it is both time consuming and expensive, widespread clinical use is not justifiable unless or until further information suggests that this significantly improves the clinical outcome of large numbers of patients.

1 Mintz GS, Painter JA, Pichard AD, Kent KM, Satler LF Popma JJ, et al. Atherosclerosis in angiographically "normal" coronary artery reference segments: an intravascular ultrasound study with clinical correlations. $\varsubsetneqq \mathrm{Am} \mathrm{Coll}$ Cardiol 1995;25:1479-85.

2 White CJ, Ramee SR, Collins TJ, Jain A, Mesa JE. Ambiguous coronary angiography: clinical utility of intravascular ultrasound. Cathet Cardiovasc Diagn 1992; 26:200-3.

3 Mintz GS, Pichard AD, Kovach JA, Kent KM, Satler LF, Javier SP, et al. Impact of preintervention intravascular in coronary artery disease. Am $\mathcal{F}$ Cardiol 1994;73:423-30.

4 Nakamura S, Colombo A, Gaglione A, Almagor Y, Goldberg SL, Maiello L, et al. Intracoronary ultrasound observations during stent implantation. Circulation 1994; 89:2026-34.

5 Serruys PW, Emanuelsson H, van der Giessen W, Lunn AC, Kiemeneij F, Macaya C, et al. Heparin-coated Palmaz-Schatz stents in human coronary arteries: early Palmaz-Schatz stents in human coronary arteries: early 93:412-22. 